\title{
Metazoan parasites of the lambari Astyanax altiparanae collected in the Batalha River, State of São Paulo, Brazil
}

\author{
D. C. Negrelli, , V. D. Abdallah ${ }^{a}$ and R. K. Azevedo ${ }^{a *}$ \\ ${ }^{a}$ Laboratório de Ictioparasitologia, Central de Laboratórios de Ciência e Tecnologia Ambiental, Pró-reitoria de Pesquisa \\ e Pós-graduação, Universidade do Sagrado Coração - USC, Rua Irmã Arminda, 10-50, CEP 17011-160, Bauru, \\ São Paulo, Brazil \\ *e-mail: azevedork@gmail.com
}

Received: November 25, 2016 - Accepted: January 31, 2017 - Distributed: October 31, 2018

\begin{abstract}
Here we conduct a qualitative and quantitative analysis of ectoparasites and endoparasites of Astyanax altiparanae (Garutti \& Britski, 2000), popularly known as lambari-do-rabo-amarelo collected from the Batalha River, State of São Paulo, Brazil. Of the 67 specimens of A. altiparanae, 52 were parasitized by at least one parasitic metazoan species. The following metazoan parasites were found: Monogenea, Digenea and Nematoda. The monogenetic Diaphorocleidus sp. was the predominant species, presenting a higher frequency of dominance, prevalence and mean abundance. However, the monogenean Trinigyrus sp. was the one with the highest mean intensity value. All parasites showed aggregate distribution pattern. The parasitic community of A. altiparanae was characterized by low diversity, low richness and low uniformity. The digenetic Rhipidocotyle santanaensis is recorded for the first time in A. altiparanae, in the same way, this parasite is being registered for the first time in the Batalha River.
\end{abstract}

Keywords: Ectoparasites, Endoparasites, Characidae.

\section{Metazoários parasitos do lambari Astyanax altiparanae coletados no rio Batalha, estado de São Paulo, Brasil}

\section{Resumo}

Foi realizada uma análise qualitativa e quantitativa de ectoparasitas e endoparasitas de Astyanax altiparanae (Garutti \& Britski, 2000), popularmente conhecido como lambari-do-rabo-amarelo coletados no rio Batalha, estado de São Paulo, Brasil. Dos 67 espécimes de A. altiparanae, 52 estavam parasitados por pelo menos uma espécie de metazoário parasito. Foram encontrados os seguintes metazoários parasitos: Monogenea, Digenea e Nematoda. O monogenético Diaphorocleidus sp. foi a espécie predominante, apresentando maior frequência de dominância, prevalência e abundância média. Porém o monogenético Trinigyrus sp. foi o que apresentou maior valor de intensidade média. Todos os parasitos mostraram padrão de distribuição agregado. A comunidade parasitária de A. altiparanae foi caracterizada pela baixa diversidade, baixa riqueza e baixa uniformidade. Registra-se pela primeira vez o digenético Rhipidocotyle santanaensis em A. altiparanae, da mesma forma, este parasito está sendo registrado pela primeira vez no rio Batalha.

Palavras-chave: Ectoparasitos, Endoparasitos, Characidae.

\section{Introduction}

Astyanax altiparanae (Garutti and Britski, 2000), belonging to the Characidae family, known as lambari-do-rabo-amarelo, is a small fish species, with omnivorous food habit, fast growth and inhabits small streams, lagoons and great rivers, being also found in large quantities in the Brazilian watersheds (Almeida, 2007). Typically, this species form two types of shoals, one with approximately 50 individuals, formed by the smaller specimens and located in the margin between the aquatic vegetation and the other with 15 individuals, formed by larger specimens found in the depths. The formation of schoals may be an anti-predatory tactic. However, shoal formations may influence increased competition for food, its increases probabilities of parasite transfer or even the risk of being caught by fishing (Suzuki and Orsi, 2008).

The biodiversity of marine and freshwater environments has been threatened, mainly by environmental problems, resulting from the degradation of these ecosystems. Thus, the great rivers of the Southeast of Brazil are suffering a continuous increase of these processes of degradation (Pinto et al., 2006), an example is the Batalha River, located on the municipality of Reginópolis, State of São 
Paulo. The Batalha River belongs to the Médio-Tietê River basin and has about $167 \mathrm{~km}$ of extension. This river's headspring is located in the municipality of Agudos and flows in the municipality of Uru in the Médio-Tietê River. It is responsible for supplying $45 \%$ of the Bauru population (Santos and Heubel, 2008).

Different studies have already been carried out on the parasitic fauna of $A$. altiparanae, among them we can mention: Barassa et al. (2003), Ferrari-Hoeinghaus et al. (2006), Azevedo et al. (2007), Lizama et al. (2008), Almeida and Cohen (2011), Abdallah et al. (2013) and Camargo et al. (2016).

The objective of this study was to develop a qualitative and quantitative analysis of the ectoparasites and endoparasites of $A$. altiparanae, to get more information about the biodiversity in the aquatic environment from the State of São Paulo.

\section{Material and Methods}

The collect of the hosts were carried out in the Batalha River, in the municipality of Reginópolis (2153'22"S 49 13'41'W), State of São Paulo, from September 2013 to February 2014. The fish were caught with simple holding nets of different meshes, grouped in lots with 5 cloths, with two meters of depth and some of them were captured with the aid of coves. After collected, the following data were recorded: standard length $(\mathrm{cm})$ and total length $(\mathrm{cm})$.

For the collection of the ectoparasites were used sieves with a mesh of $53 \mu \mathrm{m}$, in which the surface of the body, gills, nostrils and mouth were examined in stereomicroscope. Afterwards, sieves with $75 \mu \mathrm{m}$ mesh were used to collect the endoparasites and in the stereomicroscope the eyes and the body cavity were observed. The ectoparasites and endoparasites were processed according to Eiras et al. (2006).
The prevalence, intensity and abundance of each component of parasitic communities were calculated according to Bush et al. (1997). To evaluate the dispersion pattern of the parasite species in the hosts, was used the Dispersion index (ID) (Leung, 1998). To evaluate the significance statistical test $d$ was calculated (Ludwig and Reynolds, 1988). The dominance of each component of parasitic infracommunities was determined by calculating the dominance frequency and the relative dominance, following the methodology of Rohde et al. (1995). The Spearman correlation coefficient $(r s)$ was used to detect possible correlations between parasite abundance and hosts standard length (Zar, 1999).

The parasitic diversity was determined for each infracommunity by the Brillouin index $(\mathrm{H})$, as well as the Pielou index $\left(\mathrm{J}^{\prime}\right)$ and the Margalef index $(d)$ were used to evaluate, respectively, the parasite uniformity and richness. All the tests mentioned above were applied only to parasite species with prevalence higher than $10 \%$ second Bush et al. (1990). The level of statistical significance adopted was 5\%.

Vouchers of the parasite species were deposited in the Helminthological Collection of the Instituto de Biociência de Botucatu (CHIBB) of Universidade Estadual Paulista - UNESP, State of São Paulo, Brazil.

\section{Results}

Sixty seven fish were collected and analyzed. In relation to these fishes, 52 were parasitized by at least one species of parasitic metazoan. The following groups of metazoan parasites were found: Monogenea, parasitizing the surface and gills; Digenea, parasitizing the surface and eyes; and Nematoda present in the intestine. The values of prevalence, mean abundance and mean intensity are presented in Table 1, in which the parasite that presented the highest value of prevalence and mean abundance was Diaphorocleidus sp.,

Table 1. Prevalence, mean abundance, mean intensity and infection / infestation sites of the metazoan parasites of Astyanax altiparanae (Garutti and Britski, 2000) collected in the Batalha River, municipality of Reginópolis, State of São Paulo, Brazil. $\mathrm{s}=$ standard deviation.

\begin{tabular}{lcccc}
\hline \multicolumn{1}{c}{ Parasites } & Prevalence (\%) & $\begin{array}{c}\text { Mean } \\
\text { Abundance } \pm \mathbf{s}\end{array}$ & $\begin{array}{c}\text { Mean } \\
\text { Intensity } \pm \mathbf{s}\end{array}$ & $\begin{array}{c}\text { Infection / } \\
\text { infestation Sites }\end{array}$ \\
\hline MONOGENEA & 22.38 & $1.24 \pm 3.30$ & $5.53 \pm 5.08$ & Surface and gills. \\
$\begin{array}{l}\text { Diaphorocleidus sp. } \\
\text { Diaphorocleidus kabatai }\end{array}$ & 2.98 & $0.09 \pm 0.51$ & $3.00 \pm 0.00$ & Gills. \\
Cacatuocotyle sp. & 10.44 & $0.48 \pm 1.68$ & $4.57 \pm 3.05$ & $\begin{array}{c}\text { Surface and gills. } \\
\text { Cacatuocotyle guaibensis }\end{array}$ \\
$\begin{array}{l}\text { Trinigyrus sp. } \\
\text { NEMATODA }\end{array}$ & 1.49 & $0.04 \pm 0.37$ & $3.00 \pm 0.00$ & Surface and gills. \\
$\begin{array}{l}\text { Contracaecum sp. } \\
\text { Cosmoxynemoides aguirei }\end{array}$ & 1.49 & $0.15 \pm 1.22$ & $10.00 \pm 0.00$ & Gills. \\
$\begin{array}{l}\text { Procamallanus } \\
\text { (Spirocamallanus) inopinatus }\end{array}$ & 8.47 & $0.06 \pm 0.30$ & $1.33 \pm 0.58$ & Intestine. \\
$\begin{array}{l}\text { DIGENEA } \\
\text { Rhipidocotyle santanaensis }\end{array}$ & & $0.03 \pm 0.24$ & $2.00 \pm 0.00$ & Intestine. \\
(metacercariea) & & $0.13 \pm 0.55$ & $1.50 \pm 1.22$ & Intestine. \\
\hline
\end{tabular}


Table 2. Frequency of dominance and mean relative dominance of metazoan parasites of Astyanax altiparanae (Garutti \& Britski, 2000) collected in the Batalha River, municipality of Reginópolis, State of São Paulo, Brazil. $\mathrm{s}=$ standard deviation.

\begin{tabular}{lcc}
\hline \multicolumn{1}{c}{ Parasites } & $\begin{array}{c}\text { Frequency of } \\
\text { dominance }(\%)\end{array}$ & $\begin{array}{c}\text { Mean relative } \\
\text { dominance } \pm \mathbf{~ s}\end{array}$ \\
\hline MONOGENEA & & \\
Diaphorocleidus sp. & 17.91 & $0.52 \pm 3.30$ \\
Cacatuocotyle sp. & 7.46 & $0.20 \pm 1.68$ \\
\hline
\end{tabular}

Table 3. Dispersion index (ID) and statistical test $d$ of the metazoan parasites of Astyanax altiparanae (Garutti and Britski, 2000) collected in the Batalha River, municipality of Reginópolis, State of São Paulo, Brazil.

\begin{tabular}{lcc}
\multicolumn{1}{c}{ Parasites } & ID & $\boldsymbol{d}$ \\
\hline MONOGENEA & & \\
Diaphorocleidus sp. & 8.77 & 22.58 \\
Cacatuocotyle sp. & 5.89 & 16.44 \\
\hline
\end{tabular}

Table 4. Spearman $(r s)$ correlation coefficient values between the standard length of Astyanax altiparanae (Garutti \& Britski, 2000) collected in the Batalha River, municipality of Reginópolis, State of São Paulo, Brazil. ( $p=$ level of significance).

\begin{tabular}{lcc}
\hline \multicolumn{1}{c}{ Parasites } & $\boldsymbol{r s}$ & $\boldsymbol{p}$ \\
\hline MONOGENEA & & \\
Diaphorocleidus sp. & 0.17 & 0.16 \\
Cacatuocotyle sp. & -0.02 & 0.83 \\
\hline
\end{tabular}

and the parasite Trinigyrus sp. presented higher mean intensity value.

The monogenetic Diaphorocleidus sp. was the predominant species, with 83 specimens collected, as well as the parasite that presented the highest frequency of dominance (17.91\%) (Table 2).

A total of 158 specimens of parasites were collected. The parasites present the typical pattern of aggregate distribution (Table 3). There was no significant correlation between the standard length of the host body and parasitic abundance (Table 4).

The diversity index of Brillouin $(H)$ was $0.05 \pm 0.14$, the Margalef $(d)$ richness index was $0.10 \pm 0.27$ and the Pielou (J') equitability index was $0.11 \pm 0.27$.

\section{Discussion}

The results obtained in the present work indicate that the parasite community of $A$. altiparanae was characterized by low diversity, low richness and low uniformity. This can be explained by the fact that although nine species of parasitic metazoans were found, their abundance were very low. Results differents were obtained in the study of Camargo et al. (2016) with A. altiparanae in the Peixe's River, in which 15 species of parasitic metazoan were found and the parasite community was characterized by high richness and low uniformity.
Camargo (2015) carried out a study on the seasonal variation of $A$. altiparanae metazoan parasites collected at another point on the Batalha River on the municipality of Bauru, State of São Paulo, from August 2013 to July 2014 and the results were different from those found in the present study. In this study, this author found a much higher number of metazoan parasites species (18) and consequently a greater diversity and parasitic richness. This fact may be related to the different environments in which the hosts were collected, since in the work of Camargo (2015) the fish came from a lentic environment and in the present study the environment is lotic. Parasites with direct life cycle, such as monogenetics, are more easily found in lentic environments, since their free-natant larval forms (onychocytes) find the host more easily (Dogiel, 1961). Therefore, the small flow of water in this environment, allows a greater exchange of parasites between the hosts. Besides that in lentic environments the chances of contamination by parasites of indirect life cycle are higher, since the intermediate hosts of these parasites can be found more easily. Already in relation to the collection period in both studies covered the dry and rainy season, however, Camargo (2015) carried out a larger collection of hosts in the period considered dry, which may also be influencing a higher diversity and richness of parasites, since in dry periods, the water quantity of the reservoir diminishes significantly, increasing the chances of the between the parasites and their hosts, both the direct life cycle and the indirect life cycle.

There was no significant correlation between standard length of A. altiparanae and abundance of parasites. The same result was found in the work of Camargo et al. (2016). However, in the work of Lizama et al. (2008), only the parasite Ascocotyle (A) tenuicollis showed a significant correlation between standard length and abundance and prevalence of parasitism. Thus, the influence of length on parasitism is important because length is considered to determine the age of the host, thus this is one of the factors in varying the size of infrapopulations of parasites (Dogiel, 1961).

All parasites showed the aggregate distribution pattern. This pattern is found mainly in parasites of freshwater fish and the main factors of this distribution are related to physical changes in time and space, behavioral and even genetic factors (Von Zuben, 1997). The aggregation of the parasite population within a small host population increases the stability of the relationship due to regulatory mechanisms such as: host mortality dependent on parasite density and reduction in parasite survival and fecundity caused by intraspecific competition between parasites or immunological reaction of hosts (Dobson, 1990).

The nematode Contracaecum sp. was found parasitizing the intestine of this host. This parasite has a zoonotic potential and according to Smith (1999) the species belonging to the genus Anisakis, Contracaecum and Pseudoterranova are the main responsible for human infections. Even that this parasite has been found in the intestine and in low prevalence and abundance there is a risk that the larvae 
migrate to the musculature during the freezing of the fish. Such infection occurs mainly through the ingestion of raw or undercooked, smoked or salted fishes, containing infective larvae (Audicana et al., 2002).

This is the first record of $R$. santanaensis in A. altiparanae, as well as, this parasite is being registered for the first time in the Batalha River.

\section{Acknowledgements}

We thank to the Master's Degree student Lucas Aparecido Rosa Leite for checking the English and to the Fundação de Amparo à Pesquisa do Estado de São Paulo - FAPESP (Processes $n^{\circ}$ 2012/23655-0 and 2014/12862-0) for the scientific and financial support.

\section{References}

ABDALLAH, V.D., AZEVEDO, R.K. and SILVA, R.J., 2013 [viewed 25 November 2016]. Trinibaculum altiparanae sp. n., a new Dactylogyrid species (Monogenea) of the Astyanax altiparanae (Osteichthyes: Characidae) in the Peixe river, Southeastern Brazil. Neotropical Helminthology [online], vol. 7, no. 2, pp. 211-217. Available from: http://sisbib.unmsm.edu.pe/bvrevistas/neohel/ v7n2/pdf/a04v7n2.pdf

ALMEIDA, K.S.S. and COHEN, S.C., 2011 [viewed 25 November 2016]. Diversidade de monogenea (Platyhelminthes) parasitos de Astyanax altiparanae do reservatório da usina hidrelétrica de Itaipu. Saúde \& Ambiente em Revista [online], vol. 6, no. 1, pp. 31-41. Available from: http://publicacoes.unigranrio.br/index. php/sare/article/\%20viewFile/1316/753

ALMEIDA, R.B.C., 2007 [viewed 25 November 2016]. Astyanax altiparanae (Pisces, Characiformes) como modelo biológico de espécie de peixe para exploração zootécnica e biomanipulação [online]. Botucatu: Universidade Estadual Paulista, Instituto de Biociências, 199 p. Tese de Doutorado em Zoologia. Available from: http://www.ibb.unesp.br/posgrad/teses/zoologia_do_2007_ rodrigo_almeida.pdf

AUDICANA, M.T., ANSOTEGUI, I.J., CORRES, L.F. and KENNEDY, M.W., 2002. Anisakis simplex: dangerous dead and alive? Trends in Parasitology, vol. 18, no. 1, pp. 20-25. PMid:11850010. http://dx.doi.org/10.1016/S1471-4922(01)02152-3.

AZEVEDO, G.B., MADI, R.R. and UETA, M.T., 2007. Metazoários parasitos de Astyanax altiparanae (Pisces: Characidae) na Fazenda Rio das Pedras, Campinas, SP, Brasil. Bioikos [online], vol. 21, no. 2, pp. 89-96. Available from: http://periodicos.puc-campinas. edu.br/seer/index.php/bioikos/article/ view/844/823

BARASSA, B., CORDEIRO, N.S. and ARANA, S., 2003. A new species of Henneguya, a Gill Parasite of Astyanax altiparanae (Pisces: Characidae) from Brazil, with comments on histopathology and seasonality. Memorias do Instituto Oswaldo Cruz, vol. 98, no. 6, pp. 761-765. PMid:14595452. http://dx.doi.org/10.1590/ S0074-02762003000600009.

BUSH, A.O., AHO, J.M. and KENNEDY, C. R., 1990. Ecological versus phylogenetic determinants of helminth parasite community richness. Journal of Evolution and Ecology, vol. 4, no. 1, pp. 1-20.

BUSH, A.O., LAFFERTY, K.D. and LOTZ, J.M., SHOSTAK, A.W., 1997 [viewed 25 November 2016]. Parasitology meets ecology on its own terms: Margolis et al. revisited. The Journal of Parasitology [online], vol. 83, no. 4, pp. 575-583. Available from: http://www.fcfar.unesp.br/arquivos/494986.pdf

CAMARGO, A.A., 2015 [viewed 25 November 2016]. Metazoários Parasitos dos Lambaris Astyanax altiparanae Garutti \& Britski, 2000, Astyanax bockmanni Vari \& Castro, 2007 e Astyanax fasciatus (Cuvier, 1819) (Characiformes: Characidae) coletados no Rio Batalha, médio rio Tietê, SP, Brasil [online]. Botucatu: Universidade Estadual Paulista “Julio Mesquita Filho", Instituto de Biociências, 98 p. Dissertação de Mestrado em Ciências Biológicas. Available from: https://repositorio.unesp.br/handle/11449/144101

CAMARGO,A.A., NEGRELLI, D.C., PEDRO, N.H.O., AZEVEDO, R.K., SILVA, R.J. and ABDALLAH, V.D., 2016 [viewed 25 November 2016]. Metazoan parasite of lambari Astyanax altiparanae, collected from the Peixe river, São Paulo, southeast of Brazil. Ciencia Rural [online], vol. 46, no. 5, pp. 876-880. Available from: http://www.scielo.br/scielo.php?script=sci_arttext\&pid=S0103$84782016000500876 \& \operatorname{lng}=$ en\&nrm $=$ iso

DOBSON, A.P., 1990 [viewed 25 November 2016]. Models of multi-species parasites-host communities. In: G.W. ESCH, A.O. BUSH and J.M. AHO, eds. Parasite communities: patterns and process [online]. New York: Chapman and Hall, pp. 261-288. Available from: http://link.springer.com/chapter/10.1007\% 2F978-94-009-0837-6_10

DOGIEL, V.A., 1961. Ecology of the parasites of freshwater fishes. In: V.A. DOGIEL, G.K. PETRUSHEVSKI and Y.L. POLYANSKI, eds. Parasitology of fishes. (Translated by Z. Kabata). Edinburgh: Oliver and Boyd, pp. 1-47. Translation of Russian original title, published by Leningrad University Press, 1958.

EIRAS, J.C., TAKEMOTO, R.M. and PAVANELLI, G.C., 2006. Métodos de estudo e técnicas laboratoriais em parasitologia de peixes. 2. ed. Maringá: Eduem. 199 p.

FERRARI-HOEINGHAUS, A.P., TAKEMOTO, R.M., OLIVEIRA, L.C., MAKRAKIS, M.C. and BAUMGARTNER, G., 2006. Host-parasite relationships of monogeneans in gills of Astyanax altiparanae and Rhamdia quelen of the São Francisco verdadeiro river, Brazil. Parasite, vol. 13, no. 4, pp. 315-320. PMid:17285853. http://dx.doi.org/10.1051/parasite/2006134315.

GARUTTI, V. and BRITSKI, H.A., 2000. Descrição de uma espécie nova de Astyanax (Teleostei: Characidae) da bacia do alto rio Paraná e considerações sobre as demais espécies do gênero na bacia. Comunicações do Museu de Ciências e Tecnologia, vol. 13 , pp. $65-88$.

LEUNG, B., 1998. Aggregated parasite distributions on hosts in a homogeneous environment: examining the Poisson null model. International Journal for Parasitology, vol. 28, no. 11, pp. 1709-1712. PMid:9846607. http://dx.doi.org/10.1016/S00207519(98)00128-3.

LIZAMA, M.L.A.P., TAKEMOTO, R.M. and PAVANELLI, G.C., 2008 [viewed 25 November 2016]. Ecological aspects of metazoan parasites of Astyanax altiparanae Garutti \& Britski, 2000 (Characidae) of the upper Paraná river floodplain, Brazil. Boletim do Instituto de Pesca [online], vol. 34, no. 4, pp. 527-533. Available from: ftp://ftp.sp.gov.br/ftppesca/34_4_527-533.pdf

LUDWIG, J.A. and REYNOLDS, J.F., 1988 [viewed 25 November 2016]. Statistical ecology: a primer on methods and computing [online]. New York: Wiley-Interscience Publications. 337 p. Available from: http://www2.ib.unicamp.br/profs/thomas/ NE002_2011/maio12/LR\%201988\%20StatEcol\%20sel1.pdf. ISBN:0-471-83235-9 
PINTO, B.C.T., PEIXOTO, M.G. and ARAÚJO, F.G., 2006. Effects of the proximity from na industrial plant on fish assemblages in the rio paraíba do Sul, southeastern Brazil. Neotropical Ichthyology, vol. 4, no. 2, pp. 269-278. http://dx.doi.org/10.1590/S167962252006000200013 .

ROHDE, K., HAYWARD, C. and HEAP, M., 1995. Aspects of the ecology of metazoan ectoparasite of marine fishes. International Journal for Parasitology, vol. 25, no. 8, pp. 945-970. PMid:8550295. http://dx.doi.org/10.1016/0020-7519(95)00015-T.

SANTOS, F.S. and HEUBEL, M.T.C.D., 2008 [viewed 25 November 2016]. Composição da comunidade ictiológica e biometria taxonômica na lagoa de captação de água do DAE no rio Batalha (Bauru-SP). Salusvita [online], vol. 27, no. 1, pp. 29-44. Available from: http://www.usc.br/biblioteca/salusvita/ salusvita_v27_n1_2008_art_03.pdf
SMITH, J.W., 1999. Ascaridoid nematodes and pathology of the alimentary tract and its associated organs in vertebrates, including man: a literature rewiew. Helminthological Abstracts, vol. 68 , no. 2 , pp. 49-96.

SUZUKI, F.M. and ORSI, M.L., 2008. Formação de cardumes por Astyanax altiparanae (Teleostei: Characidae) no Rio Congonhas, Paraná, Brasil. Revista Brasileira de Zoologia, vol. 25, no. 3, pp. 566-569. http://dx.doi.org/10.1590/S0101-81752008000300026.

VON ZUBEN, C.J., 1997. Implicações da agregação espacial de parasitos para a dinâmica populacional na interação hospedeiroparasito. Revista de Saude Publica, vol. 31, no. 5, pp. 523-530. PMid:9629733. http://dx.doi.org/10.1590/S0034-89101997000600014.

ZAR, J.H., 1999. Biostatistical analysis. 4th ed. New Jersey: Prentice-Hall. 663 p. 